\title{
ERTS DATA IN GLACIOLOGY-AN EFFORT TO MONITOR GLACIER MASS BALANGE FROM SATELLITE IMAGERY
}

\author{
By Gunnar Østrem
}

(Hydrologisk Avdeling, Norges Vassdrags- og Elektrisitetsvesen, Postboks 5091-Mj., Oslo 3, Norway and Naturgeografiska Institutionen, Stockholms Universitet, Box 680 I, I I 386 Stockholm, Sweden)

Abstract. Due to increased demand for electric energy, which in Norway is produced almost entirely by hydro-electric power plants, extensive glacierized basins are now considered for future power production. However, glacier behaviour has a great impact on the annual run-off from these basins, and information about expected annual deviations from a "normal" discharge must be obtained from mass-balance studies on representative glaciers within the basin. For this reason such studies are presently performed at eight selected Norwegian glaciers; the costs involved are in the order of $\$ 3$ ooo- $\$ 10$ ooo annually for each observed glacier.

The transient snow line can be identified easily on conventional air photographs and its height determined by direct comparisons with reliable topographic maps (with contour lines on glaciers). The resolution in ERTS images is sufficiently good to use the satellite data for a similar height determination of the transient snow line on glaciers - at least on the larger valley glaciers and, of course, on ice caps.

Due to an existing correlation between the height of the transient snow line (at the end of the melt season) and the annual specific net mass balance, it is possible to construct a diagram expressing this relationship, provided detailed mass-balance studies have been performed during a period of several years of different mass-balance conditions (ideally comprising both years of negative and of positive net balances). Determinations of the transient snow-line height based upon ERTS data, obtained at the end of the summer season, can then be used to determine the mass balance for those glaciers where the above-mentioned relationship is established. This would be a great advantage in cases where there is a request for information on the net balance only; no separate data on winter balance or summer balance will be obtained by this method.

Experiments have been performed to delineate the transient snow line on glaciers directly from ERTS digital data (CCT magnetic tape). The results indicate that last winter's snow is characterized by grey levels $41-48$ (of 63 possible grey-scale levels) on MSS-7, whereas exposed glacier ice is represented by levels 13-20 in the same multi-spectral band. Snow and ice can also be separated on MSS-4, but the difference in grey-scale levels between the two materials is much smaller.

RÉSUMÉ. Les données ERTS en glaciologie - un essai pour deduire des bilans glaciaires à partir d'images de satellite. En raison de la demande accrue d'énergie électrique qui, en Norvège, est presque entièrement d'origine hydro-électrique, de grands bassins englacés sont actuellement examinés du point de vue de leurs possibilités de production future d'énergie. Quoiqu'il en soit, les comportements des glaciers ont une influence importante sur les écoulements annuels en provenance de ces bassins et une prévision des variations annuelles attendues par rapport à un débit "normal" peut être basée sur des études de bilans dans des glaciers représentatifs du bassin. C'est pourquoi, de telles études sont actuellement conduites sur huit glaciers sélectionnés en Norvège; les coûts annuels sont de l'ordre de 3 ooo à 18 ooo \$ annuellement pour chaque glacier observé.

La ligne provisoire des névés peut facilement être identifiée sur des photographies aériennes conventionnelles et sa hauteur repérée par des comparaisons directes avec des cartes topographiques valables (avec courbes de niveau sur le glacier). La résolution des images ERTS est assez bonne pour utiliser les données du satellite pour déterminer de la même manière la hauteur de la ligne provisoire des névés sur les glaciers au moins sur les plus larges glaciers de vallée et, bien sûr, sur les calotte glaciaires.

Comme il y a une corrélation entre la hauteur de la ligne provisoire des névés (à la fin de la saison d'ablation) et le bilan spécifique net annuel, on peut construire un diagramme exprimant cette relation, pourvu que des études détaillées de bilan aient été poursuivies pendant plusieurs années à bilans différents (comprenant si possible des bilans positifs et des bilans négatifs). Si cette relation est connue, on peut alors utiliser les déterminations de la ligne provisoire des névés en fin d'été pour estimer les bilans de ces glaciers. Ceci serait d'une grande utilité au cas où l'on n'aurait besoin que du bilan annuel; mais cette méthode ne permet pas de distinguer séparément les apports d'été et d'hiver.

On a essayé de distinguer la ligne provisoire des névés sur les glaciers directement à partir des données digitales de ERTS (touches magnétiques CCT). Les résultats montrent que la neige du dernier hiver est caractérisée par un degré de gris $4^{1}$ à 48 (parmi les 63 degrés possibles de l'échelle des gris) sur le MSS-7 tandis que la glace de glacier découverte est représentée par des degrés i 3 à 20 sur la même bande multispectrale. La neige et la glace peuvent aussi être séparées par le MSS-4, mais la différence dans les degrés de l'échelle des gris des deux matériaux est beaucoup plus petite.

Zusammenfassung. ERTS-Daten in der Glaziologie - ein Versuch zur Bestimmung von Gletscher-Massenhaushalten aus Satellitenbildern. Infolge des erhöhten Bedarfes an elektrischer Energie, die in Norwegen fast ausschliesslich in Wasserkraftwerken erzeugt wird, werden jetzt stark vergletscherte Täler im Hinblick auf zukünftige Energieproduktion untersucht. Das Verhalten der Gletscher ist von grosser Bedeutung für den jährlichen Abfluss aus diesen Tälern; Daten über voraussichtliche jährliche Abweichungen von einem 
"normalen" Abfluss müssen aus Massenhaushaltsstudien an repräsentativen Gletschern innerhalb des Einzugsgebietes gewonnen werden. Deshalb werden derzeit solche Studien an 8 ausgewählten norwegischen Gletschern durchgeführt. Die anfallenden Kosten liegen in der Grössenordnung von 3 ooo-10 ooo Dollar pro Jahr für jeden beobachteten Gletscher.

Die temporäre Schneegrenze kann leicht in konventionellen Luftbildern festgestellt, ihre Höhe durch direkten Vergleich mit zuverlässigen topographischen Karten (mit Höhenlinien auf den Gletschern) bestimmt werden. Die Auf lösung in ERTS-Bildern ist hoch genug, um die Satellitendaten für eine ähnliche Höhenbestimmung der temporären Schneegrenze auf Gletschern zu ermitteln - zumindest auf grösseren Talgletschern und natürlich auf Eisschilden.

Infolge der Korrelation zwischen der Höhe der temporären Schneegrenze (am Ende der Schmelzperiode) mit dem jährlichen spezifischen Nettomassenhaushalt ist es möglich, ein Diagramm für diese Beziehung zu konstruieren, vorausgesetzt, dass sorgfältige Massenhaushaltsstudien über eine mehrjährige Periode mit unterschiedlichen Haushaltsbedingungen vorliegen; im Idealfall sollten sie sowohl Jahre mit negativem wie mit positivem Nettohaushalt umfassen. Bestimmungen der Höhe der temporären Schneegrenze aus ERTS-Bildern vom Ende der sommerlichen Jahreszeit können dann zur Ermittlung des Massenhaushaltes für solche Gletscher herangezogen werden, bei denen die erwähnte Beziehung bekannt ist. Das bedeutet einen grossen Vorteil in den Fällen, wo nur die Kenntnis der Nettobilanz benötigt wird; zwischen Winterund Sommerhaushalt wird dann nicht unterschieden.

Es wurden Versuche zur Kartierung der temporären Schneegrenze auf Gletschern unmittelbar aus den digitalen ERTS-Daten (CCT-Magnetband) unternommen. Die Ergebnisse zeigen, dass der Schnee des letzten Winters durch die Grauwerte $4{ }^{1-48}$ (bei 63 möglichen Werten auf der Grauskala) im Spektralband 7 gekennzeichnet ist, während nacktes Gletschereis mit den Werten ${ }^{1} 3^{-20} \mathrm{im}$ selben Spektralband wiedergegeben wird. Schnee und Eis können auch im Spektralband 4 unterschieden werden, doch ist der Unterschied zwischen den Grauwerten für beide Materialien hier viel kleiner.

\section{INTRODUGTION}

Almost all electric power in Norway is produced in hydro-electric power plants, in general utilizing water stored in reservoirs at high altitudes or, to a smaller extent, utilizing river water with a relatively small head. Most of the rivers suitable for such low-head power production have been developed and the major remaining potential water power in Norway is therefore connected to high-head projects in mountainous areas. In general, these are situated in south-west and north Norway. Until recently all high-head power plants were located in almost glacier-free areas, but due to increased demand for water power it has been necessary to approach heavily glacierized basins for future developments. In general, these are three glacierized areas now considered for water power development:

the ice cap Folgefonni (south-east of Bergen),

the Jostedalsbre area (north of the Sognef jord),

the Svartisen area (in northern Norway close to the Arctic Circle).

A power station has already been installed at Mauranger, west of Folgefonni, and melt water from the western part of the ice cap contributes considerably to the high-altitude reservoirs constructed for this power station. Not less than $62 \mathrm{~km}^{2}$ (or $38 \%$ ) of the total catchment area $\left(162 \mathrm{~km}^{2}\right)$ is glacier-covered, so the glacier mass balance has a great influence on the annual inflow into the reservoirs. However, due to the short period this power station has been operating (only a few months) no experience has yet been gained concerning the impact of glacier variations on power production. It is, however, quite obvious that there will be a considerable variation in the amount of water available for power production between years of positive and years of negative mass balance.

This variation is expected to be somewhat diminished by the fact that years of positive glacier mass balance are often combined with "wet summers", i.e. the liquid precipitation shows, in general, above-normal figures in years of glacier growth. Further, in most of these years the winter precipitation has also been heavy (in fact this is one of the reasons for a positive mass balance), and this snow adds considerably to the run-off from non-glacierized parts of the basin. Similarly, years of negative mass balance are mostly associated with less snow accumulation and, not least, with hot and dry summers. 
The effect of glacier growth on river discharge in any given year would, theoretically, equal the total net balance, but the above-mentioned weather conditions will in most cases work in the opposite direction, and the impact on the annual inflow to the reservoirs due to glacier growth or shrinkage can be expected to be somewhat smaller than the total net balance.

An important glacierized area that will be developed in the future is the northern part of the ice cap Jostedalsbreen where a "roof-gutter system" will collect water at a relatively high altitude and store it in an artificial reservoir at an altitude of $c$. I $000 \mathrm{~m}$ a.s.l. The production

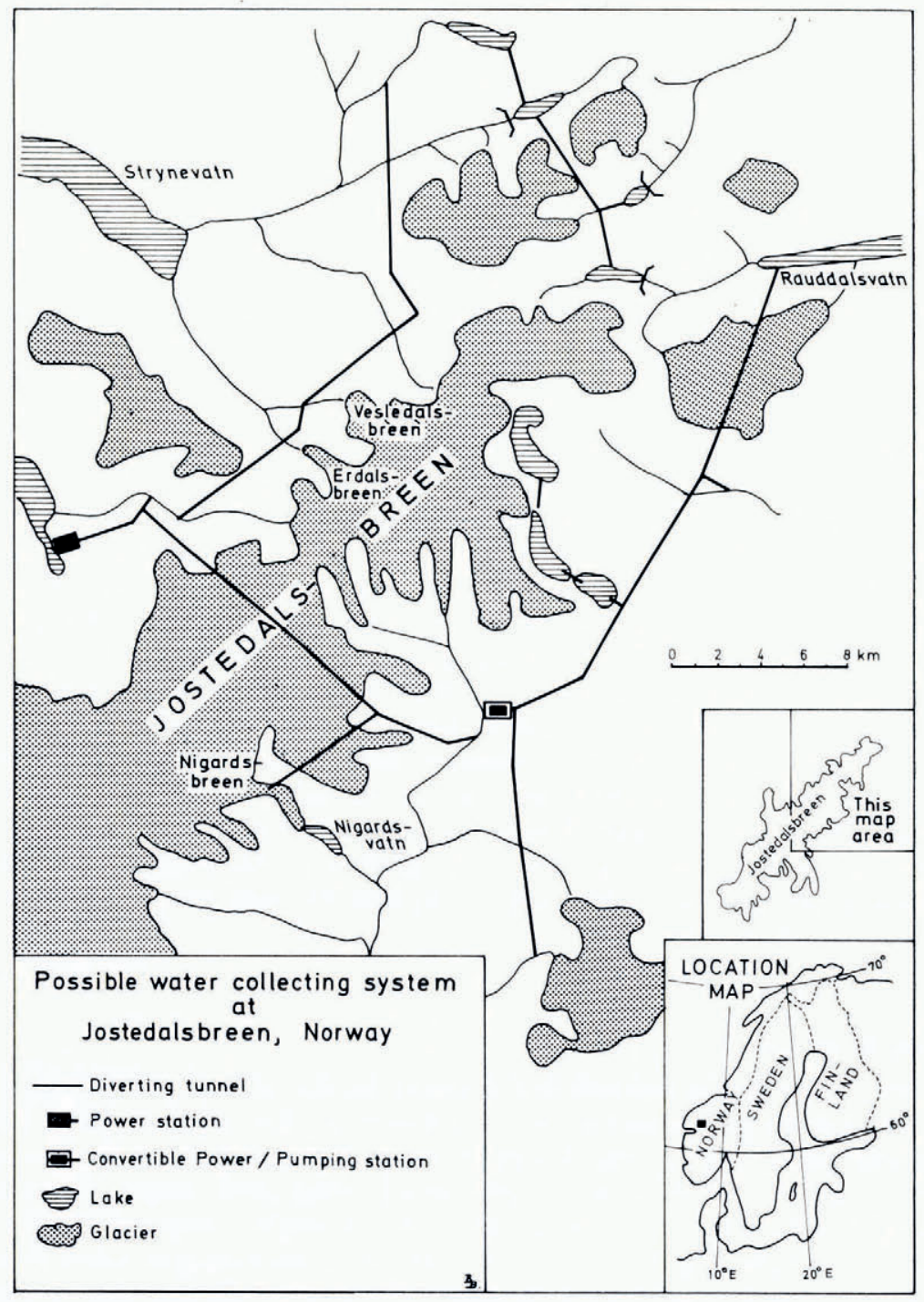

Fig. I. It is proposed to utilize melt water from the north-eastern part of the ice-cap Jostedalsbreen and adjacent glaciers to produce hydro-electric energy in a power station at the lake Loenvatn (middle left). A system of tunnels collects water from numerous rivers in the area and some of the natural lakes will be dammed to form storage basins for power production in the winter. 
of electric energy will take place at a power plant close to sea-level, but some of the energy generated in summer time (during peak flood conditions) will be used to pump water up into the main reservoir (Fig. I). This pumping is necessary because the peak power demand occurs during winter time, i.e. when the natural run-off from glacierized basins is at a minimum. Experience has shown that many glacier streams discharge about $80 \%$ of the annual run-off during only three months in the summer. A large water-storage capacity is therefore vital for a hydro-electric power-generating system utilizing glacier melt water. Substantial variations in expected water inflow, i.e. deviations from "normal" conditions, can be caused by glacier influence on river hydrology in glacierized basins and cause problems for storage management. A good knowledge of annual glacier variations, i.e. the net mass balance, is therefore important for an economically meaningful operation of many hydro-power systems in Norway.

\section{Mass-Balance inVestigations}

For planning purposes it is necessary for water-power engineers to obtain basic data on the expected run-off from glacierized basins. Therefore, mass-balance investigations were started on one outlet glacier from the ice cap Jostedalsbreen in 1962 (Østrem and Karlén, [1963]), and during the following years a selection of other glaciers were incorporated in the study program (Østrem, 1964; Østrem and Liestøl, 1964). Results from these mass-balance measurements have been used in various hydrological calculations. For example, several new river discharge gauging stations had been installed in the early 1960's, mainly in basins considered for water-power development. However, annual discharge data from many such stations could not be used directly because glacier behaviour caused "errors" in the data material. The annual run-off proved to be much larger in years of glacier shrinkage and, correspondingly, too small during years of glacier growth. Therefore, one must apply a "correction" to the actually observed amount of water, by subtracting or adding a volume corresponding to glacier shrinkage or glacier growth for any given year. In this way a "normal" annual discharge can be calculated, i.e. the theoretical discharge that would appear if the glaciers were in a steady state. This involves detailed mass-balance studies on several glaciers, carefully selected to give representative data for the calculations.

Mass-balance investigations involve extensive field work and are expensive, and it is therefore important to try to find methods or means to reduce the overall costs for this kind of investigation. At present, Norges Vassdrags- og Elektrisitetsvesen conducts a program of continuous mass balance studies at some eight glaciers in Norway, and the mean cost for labour, transportation, etc., is of the order of $\$ 3$ ooo- $\$ 10$ ooo per year per glacier under study.

\section{The TRANSIENT SNOW LiNE}

The transient snow line is defined as the lower border of last winter's snow. On most glaciers it will be clearly visible as the border between a white blanket of last winter's snow and the less white glacier ice or firn. It can be easily distinguished on air photographs (see Fig. 2) and its height can be determined from good topographic maps. The results from a study of the height of the transient snow line in western Canada is reported by Østrem (i 973 ). This study was based upon a great number of vertical air photographs taken simultaneously of a large number of glaciers in western Canada. The result indicated that the height of the transient snow line reached approximately similar altitudes for most glaciers within a certain area. It was also shown that the transient snow line (as of a given day) tends to reach higher altitudes in regions of increased continentality. 


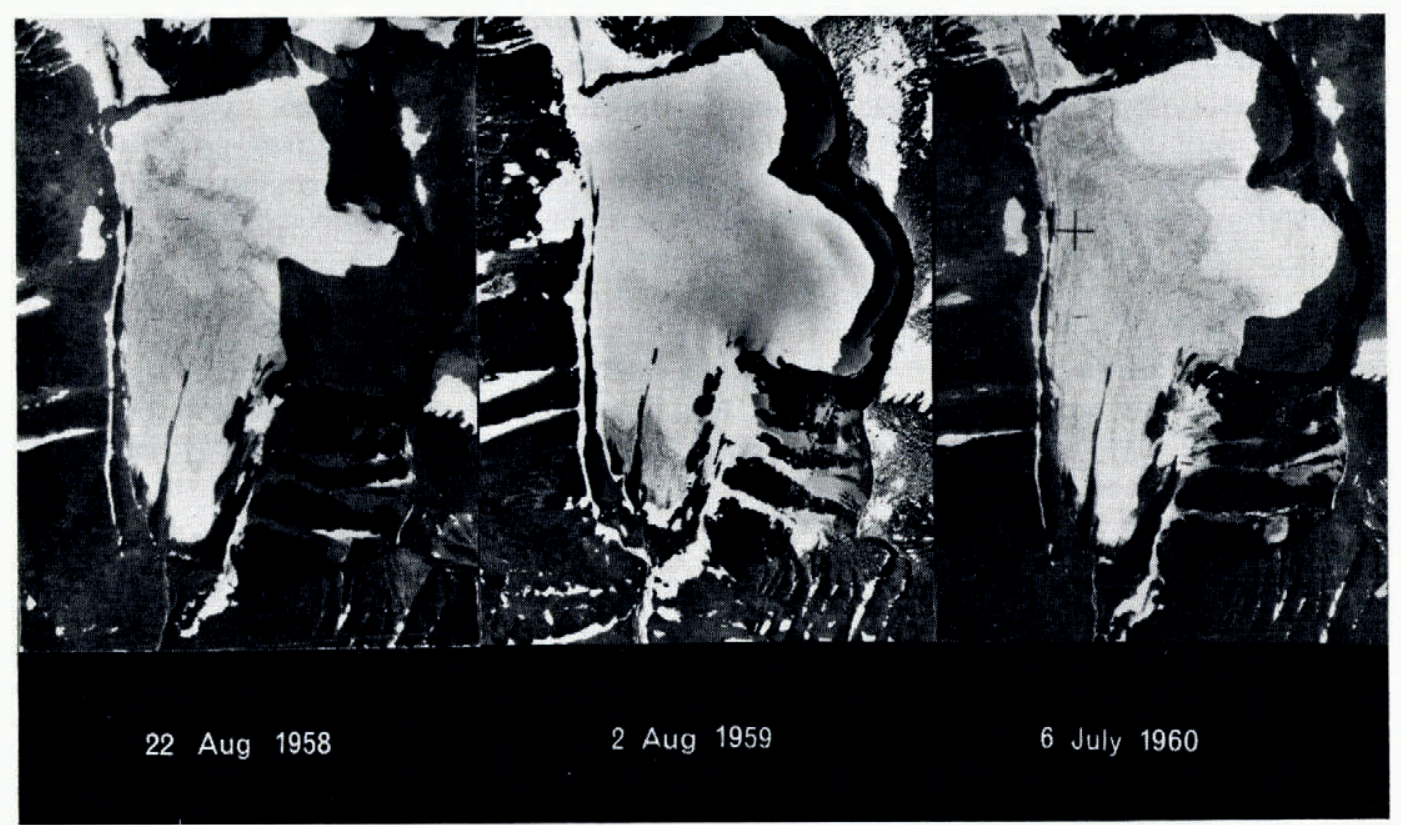

Fig. 2. The transient snow line can be seen on air photographs as the lower border of last winter's snow. In years of heavy snow accumulation or little summer melt (or both) it does not climb very high up on the glacier (middle picture). In a year with more normal conditions it may reach a position close to the equilibrium line of the glacier at the end of the summer season (left-hand picture). During exceptionally hot summers it might reach the very highest parts of the glacier (right-hand picture). The pictures show the glacier Stuor Räitavagge in Sweden, approx. scale 1: 50 ooo.

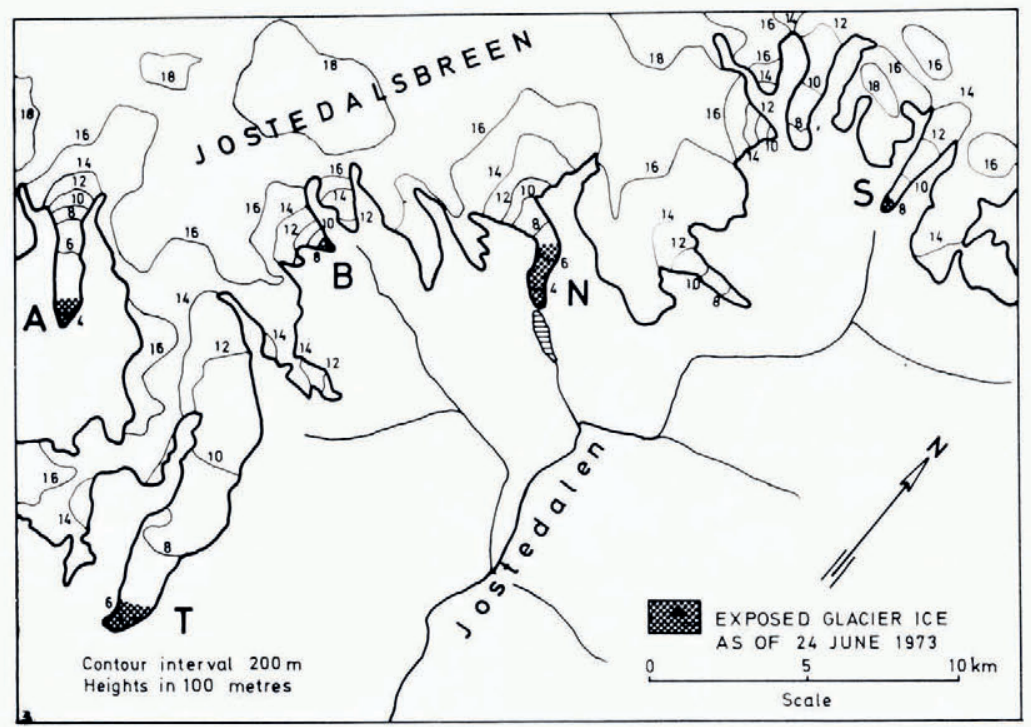

Fig. 3. From the ERTS image No. 1336-1026o it was possible to determine areas of exposed ice on five outlet glaciers. The transient snow line appeared this year at an unusually low altitude due to heavy snowfalls late in the spring. 
Such studies cannot be repeated frequently for obvious reasons-it is unrealistic to request that extensive glacierized areas be re-photographed at intervals during one season or at the end of each summer. Therefore, it was hoped that data from the ERTS satellite would have a resolution sufficiently good to identify the transient snow line on glaciers. An I $8 \mathrm{~d}$ imagery repetition would make possible a determination of the highest position of the transient snow line towards the end of the ablation season, and such information is most valuable, because it can be used for mass-balance studies, as we shall see below.

\section{RESULTS FROM ERTS-I}

On the sixth day after launch, the ERTS satellite imaged the northernmost glacier in Scandinavia, the ice-cap Seilandsjøkulen, and the transient snow line was clearly shown, particularly in MSS-7. During the rest of the summer 1972 the weather conditions unfortunately prevented further useful imagery of glacierized areas suitable for studies of the transient snow line, but it was quite clear that it could be identified on ERTS images.

The next useful ERTS image was obtained on 24 June r973. From this image (No. 1336-1026o) it was possible to determine the height of the transient snow line on five outlet

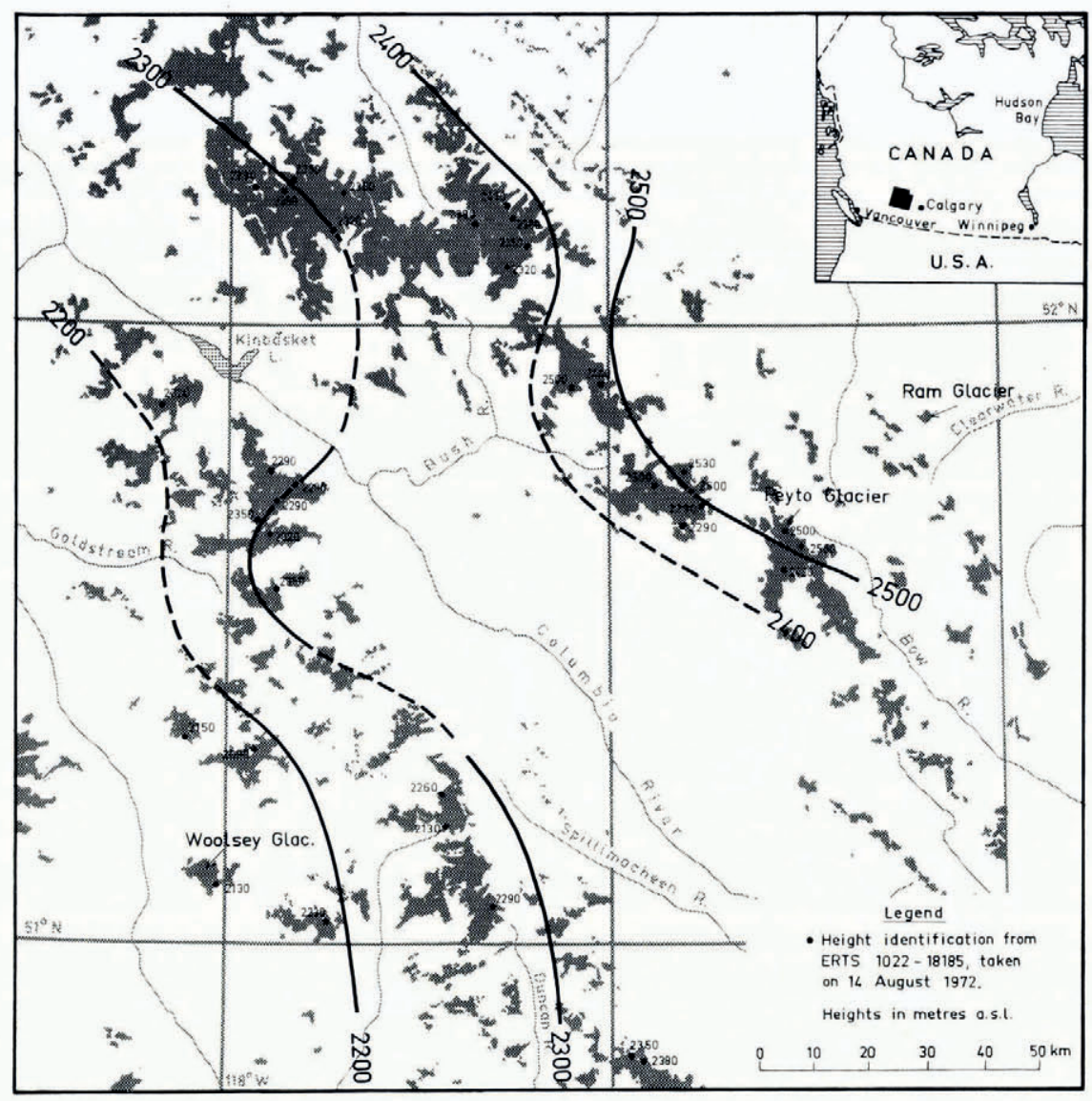

Fig. 4. The height of the transient snow line was determined on $3_{6}^{6}$ individual glaciers and contours were drawn for a theoretical surface intersecting the landscape at a height corresponding to the transient snow line position as of 14 August 1972. 
glaciers from the ice cap Jostedalsbreen (see Fig. 3). It was, however, not possible to follow the increase in snow-line heights throughout that summer because no more good ERTS images were obtained during the melt season. This was, of course, due to technical limitations on board the spacecraft, combined with weather conditions.

Due to lack of good images from Scandinavia the author continued similar work on images taken over the Canadian Rocky Mountains. On two different occasions it was possible to determine the height of the transient snow line on a relatively large number of glaciers, viz. on 14 August 1972 and on 8-9 August 1973. The results are shown in Figures 4, 5, 6 and 7.

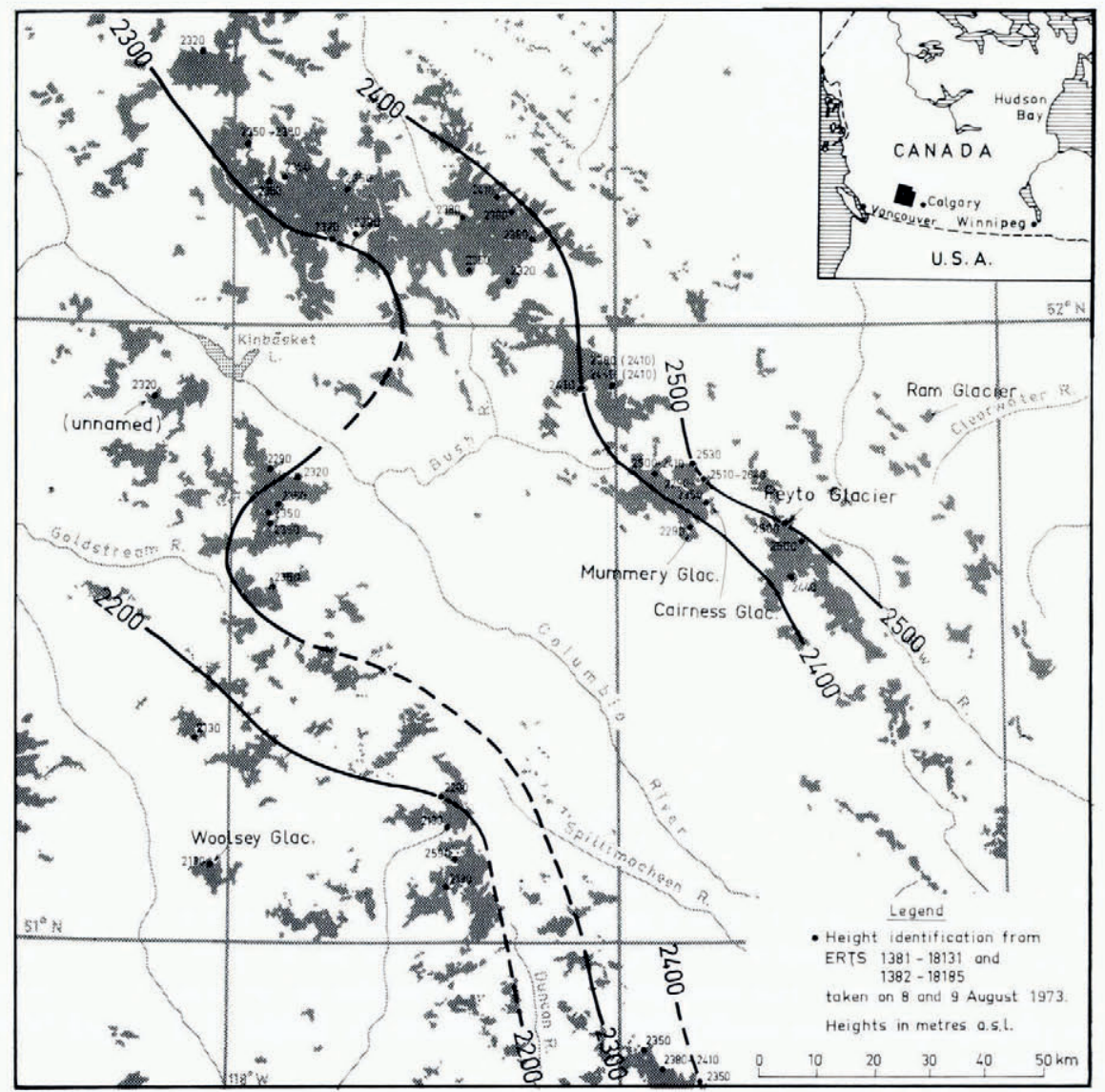

Fig. 5. From two ERTS images obtained on two consecutive days a similar determination was made as shown in Figure 4, this time on 40 glaciers. When contour lines were drawn a similar pattern was found as for the situation obtained in 1972. Note that some glaciers always show a snow-line height deviating from the "normal". For example, in both years the Mummery Glacier showed an altitude $100 \mathrm{~m}$ lower than could be expected in that area, whereas an unnamed glacier south west of Kinbasket Lake indicated both years too high a figure. Apart from such single deviations, the transient snow line will be located at similar altitudes within the same mountain massif (as of a given day).

\section{The RELATION BETWEEN TRANSIENT SNOW LINE AND MASS BALANCE}

There exists an obvious connection between the height of the transient snow line at the end of the summer and the glacier's net mass balance: for example, during years of strongly negative mass balance the transient snow line will reach its highest positions, and vice versa. Further, on most temperate glaciers, the transient snow line will, in any given year, climb to a 

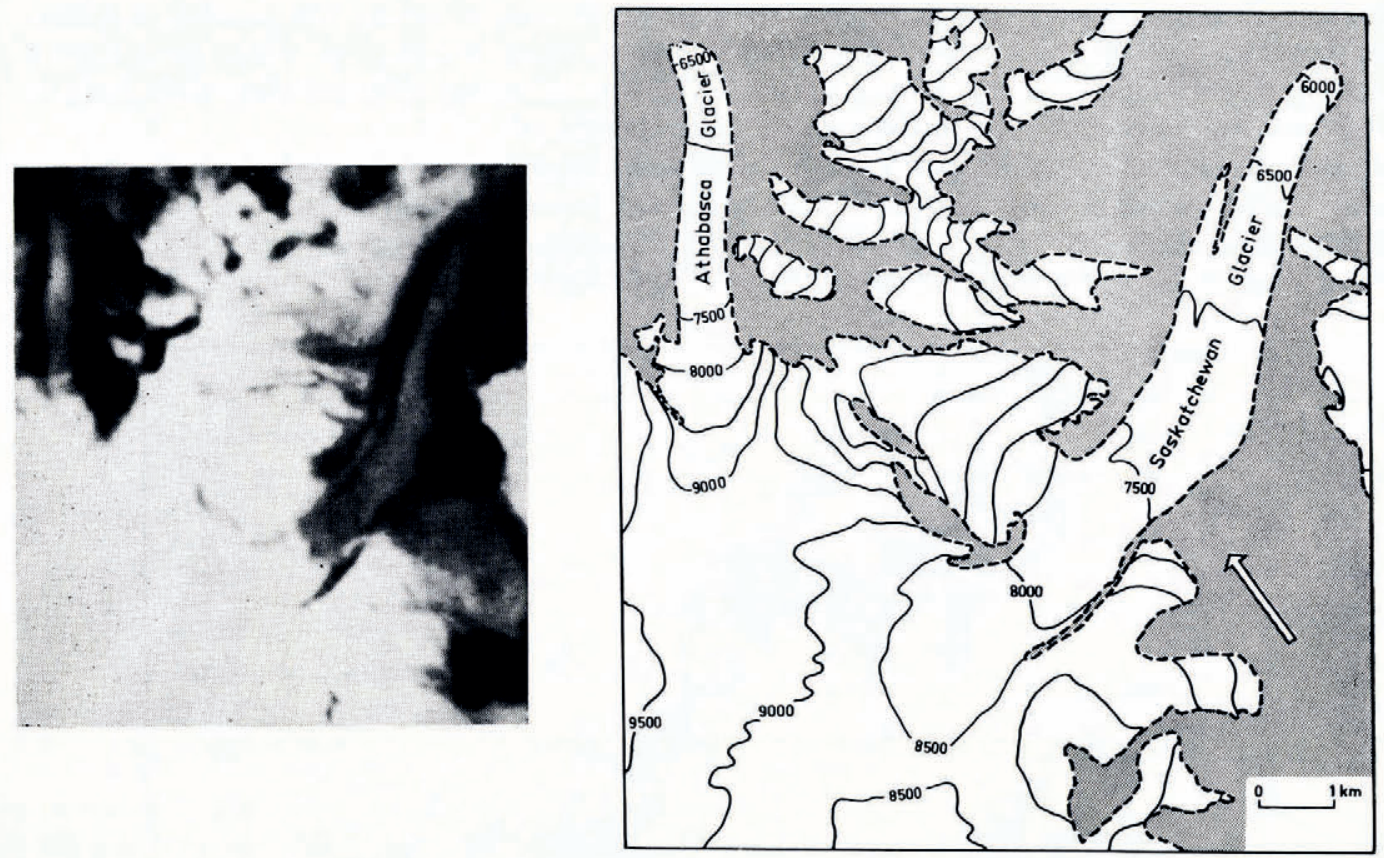

Fig. 6. A part of ERTS image No. 1332-18185 taken on 9 August 1973 over the Canadian Rocky Mountains showing the Saskatchewan and Athabasca Glaciers (left). The map is redrafted from the Canadian Topographic Map System ${ }_{3} C_{3}-$ Columbia Icefield (right). Transient snow lines can be seen on the image, and their altitude determined from the contour map. Compare Figures 4 and 5, where results for larger regions are shown. Contour heights are shown in feet on this map, but were converted to metres when results were plotted on Figures 4 and 5 .

height which is almost identical with the height of the equilibrium line for that year. Only in cases where the glacier surface happens to be fairly flat it is possible that a zone of superimposed ice might be seen between areas of last winter's snow and areas of completely uncovered glacier ice (compare Fig. 2, left-hand part). If such a picture is obtained at the end of the melt season, the equilibrium line will be situated at the lower edge of the superimposed ice zone, because superimposed ice is a part of the last winter's accumulation on the glacier surface. Apart from this small difference in position caused by the presence of some superimposed ice, it is relevant in this connection to use the height of the transient snow line (as seen on air photographs or on satellite images) to indicate the height of the equilibrium line for a given glacier.

Results from current mass-balance investigations in Canada and in Scandinavia (see, for example, Schytt, 1966 , p. 44-46) indicate that there is a good correlation between the specific net mass balance and the height of the equilibrium line at the end of the melt season (cf. Figs 8 and 9). Consequently, if the height of the transient snow line could be determined by satellite imagery, this would be a valuable tool in mass-balance investigations.

Before the satellite data can be used for this kind of glaciological work, it is necessary that detailed mass-balance studies have already been performed throughout a series of years, so that the above-mentioned correlation has been established. Ideally both years of negative and of positive net mass balance should be represented in the observation series, so that a correlation diagram can be constructed comprising the widest possible range of net mass-balance conditions (compare Fig. 9). For glaciers where mass-balance studies have been performed during a long series of years, it might happen that improved field techniques, etc. make it 


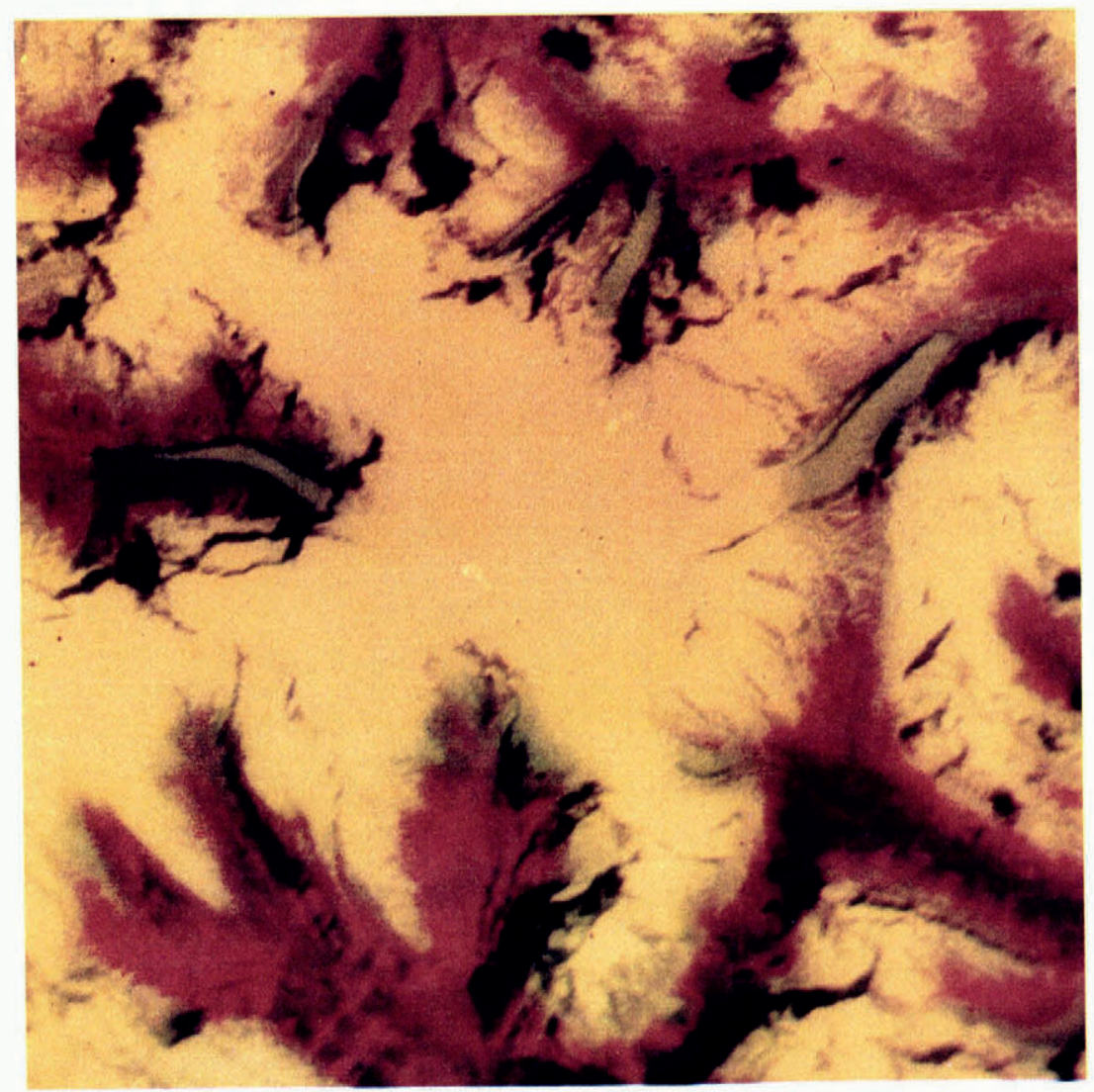

Fig. 7. Part of ERTS image No. 1741-18045 taken on 3 August 1974, showing the Columbia Icefield and its outlet glaciers.

This colour composite picture was generated in an additive projector from positive transparencies supplied by the Canadian Centre for Remote Sensing. The following colours were used: MSS 5 - green, MSS 7 - red. This colour combination gave, in this case, the best contrast for determination of the transient snowline-with yellow snow fields and a blue-green colour on exposed glacier ice. Vegetation shows up in red, whereas black indicates areas of dark shadow or clear-water lakes. Silty water will be shown in a dark greenish colour. Such lakes would be more emphasized if MSS 4 were also included in the production of the colour composite picture, but this was not done because the main objective was to identify transient snow lines.

For scale and orientation, compare with the map in Figure 6, right-hand part. The outlet glacier to the left is Columbia Glacier. On the original, silty lakes can be seen in front of the Columbia Glacier and the Athabasca Glacier. (Colour selection by S. SmithMeyer, Photograph by H. P. Østrem. 
PEYTO GLACIER, CANADA

$1965-72$

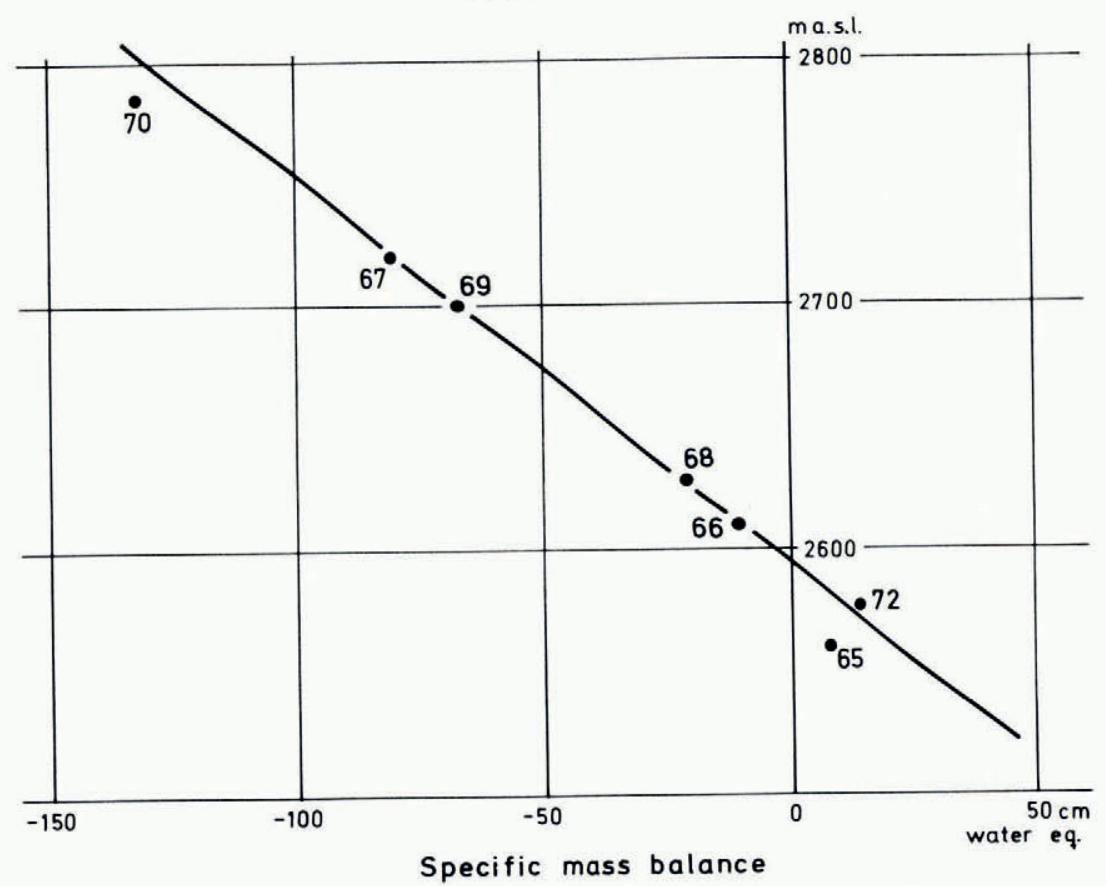

Fig. 8. There is a definite relation between the height of the equilibrium line at the end of the ablation season and the specific net mass balance. This diagram is based upon annual mass-balance investigations performed by the Canadian Department of Energy, Mines and Resources and Department of the Environment since 1965 (personal communication from A. Stanley).

necessary to select the most reliable results and discard other, in general older, results (compare Schytt, 1967, p. 329) before the diagram is constructed. Provided a good satellite imagery is obtained at the end of a summer season, the height of the transient snow line can be easily determined from a topographic map and, finally, the specific net mass balance is found from the correlation diagram (of the type shown in Fig. 9).

Obviously one is thus obtaining only the specific net mass balance for a given glacier-no separate information will be available regarding the winter balance or the summer balance. However, for engineering purposes a single figure for the specific net balance is sufficient; this is used in the hydrological calculations to obtain a "normal" run-off figure for glacierized basins.

For most glaciological studies on the other hand, and particularly for detailed studies of winter accumulation and summer melt or relations between weather conditions and mass balance, results produced by this method cannot compete at all with data obtained by conventional methods, i.e. mainly field work on the glacier proper.

\section{USE OF Digital DATA}

The method mentioned above is based upon analogue data from ERTS-i.e. the data are in general given as four black-and-white images, one for each of the spectral bands. On such images, provided by NASA as transparancies or photographic prints, it is possible to distinguish between a maximum of 15 grey-scale levels. This number of grey-scale levels, 
NIGARDSBREEN, NorwaY
$1962-72$
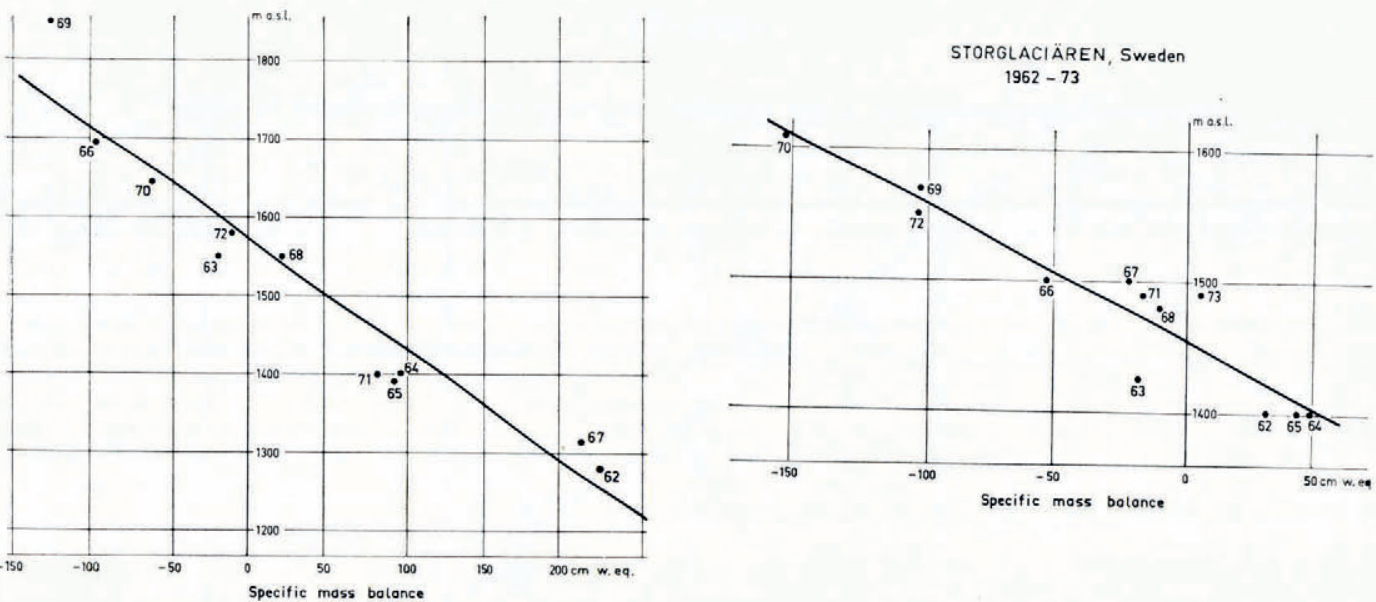

GRÅSUBREEN, NorWaY

AlFotBreEn, Norway $1963-72$
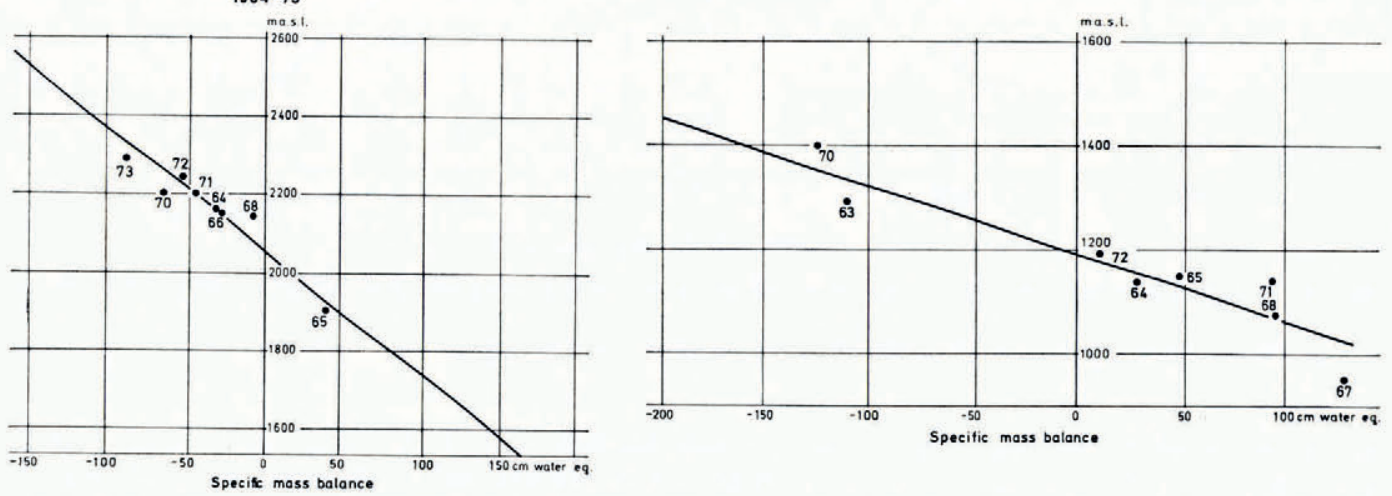

Fig. 9. Correlation diagrams for some Scandinavian glaciers were constructed to demonstrate the relation between the height of the equilibrium line and specific mass balance. In some cases a single year's observations are missing, because it happened that the transient snow line was located below or above the glacier (i.e. the glacier was completely snow-covered or snow-free at the end of the summer), and thus its height could not be defined.

and the contrast in the products delivered, is sufficient to allow the interpreter to distinguish between areas of snow or ice and areas of snow-free ground (in MSS-4) and the images are also useful to distinguish between snow and ice (in MSS-7). However, to investigate whether a more detailed analysis could be done directly from digital data (computer-compatible magnetic tape) an experiment was carried out with a selected ERTS scene. The glacier Seilandsjøkulen and adjacent ground were selected for the study, and this section was taken from a magnetic tape provided by NASA (ERTS No. 10o6-o948I).

A line-printer map of the glacier was produced from the original MSS-7 data, (see Fig. Io) and a further analysis showed that the reflectance from last winter's snow, as seen from ERTS on 29 July 1972 , was represented by the grey scale levels $4 \mathrm{I}-48$. There is provided a 63-level scale in the digital data, so an even higher brightness can be recorded, although the snow was shown as completely white areas on the photographic images. Further, glacier ice was represented by grey scale levels I $^{-20}$ whereas adjacent bedrock had only a slightly lower brightness represented by levels $7-\mathrm{I} 2$. 


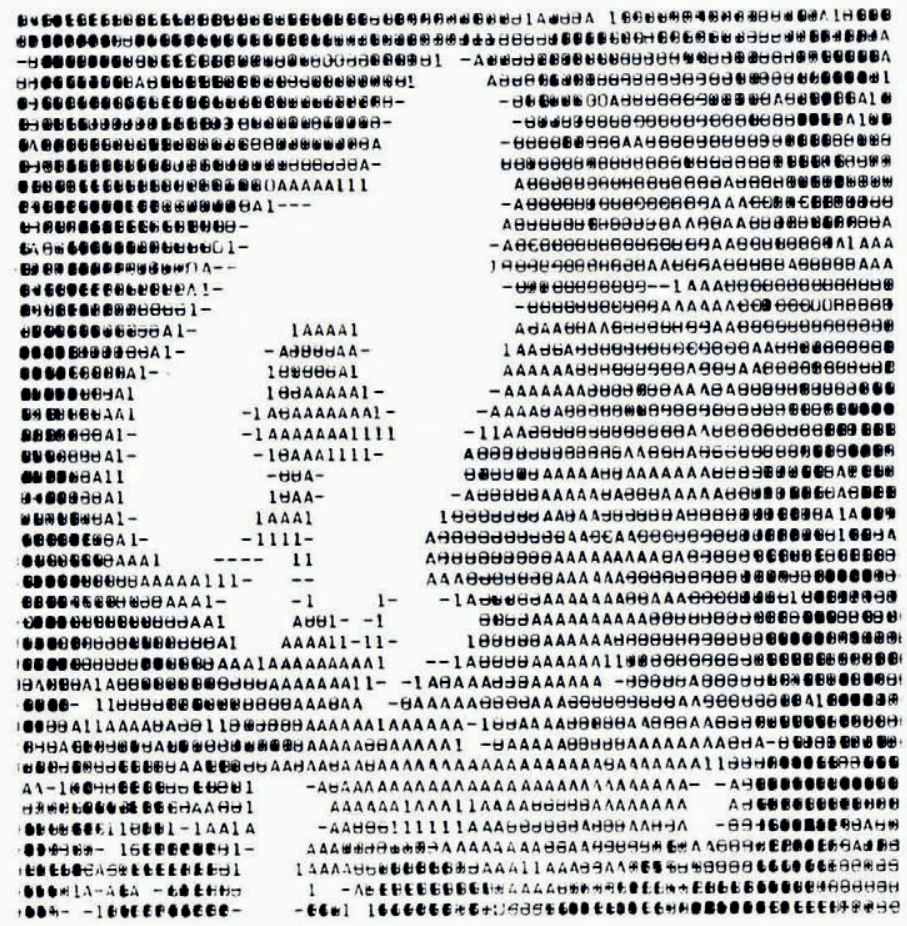

Fig. Io. A "map" produced by a computer line printer from ERTS-I digital data (MSS-7). The white areas represent last winter's snow whereas grey areas represent exposed glacier ice on the ice cap Seilandsjokulen in northern Norway. Darker areas indicate bedrock or water. Each letter or sign (with a surrounding rim) indicates one "pixel" which covers $56 \mathrm{~m} \times 79 \mathrm{~m}$ on the ground. Approximate scale $I: 50$ ooo. The computer program used for the construction of this map was written by I. Akersten.

In band MSS-4, however, last winter's snow gave a much higher reflectance, represented by a grey-scale level ranging from $55^{-62}$, and glacier ice gave levels $39^{-4} 44$ on the 63 -level scale. Thus, the difference between snow and ice was less pronounced in MSS-4 than in MSS-7. On the analogue MSS-4 material (transparencies or prints) it was not possible to see any difference between snow and ice at all. (Note: the grey-scale levels quoted above are only correct for a given latitude and a given date, because the effect of solar angle on brightness needs to be considered before one can extrapolate or generalize the results to different times or different localities.)

By this digital method it may be possible to automate determination of the transient snow line, and areas covered by last winter's snow (or the entire glacier surface) may be measured automatically, but so far only relatively simple experiments have been made and more research is necessary along these lines.

\section{Conclusion}

Images or digital data from the ERTS-I satellite have been used to determine the position of the transient snow line on glaciers and its height has been found by comparison with topographic maps. This method is in general similar to a method utilized in the past when conventional air photographs were used. There seems to be a (linear) relationship between the height of the transient snow line at the end of the summer season and the specific net mass balance. This makes possible a determination of the net mass balance for a glacier from 
ERTS data if they are obtained at the end of the ablation season, provided detailed massbalance studies throughout a series of years have been made at the glacier in question, so that the said relationship is known. Digital data may in the future be better to use for the determination of the transient snow line on glaciers, but a standard program for such work has not yet been developed.

\section{Acknowledgements}

The author had the advantage to be selected by NASA as a "Principal Investigator" throughout the first ERTS experiment, and as such he was provided with ample valuable data material, free of charge. Further, the Department of Physical Geography at the University of Stockholm gave access to their "Ad-col" viewer for the production of colour-composite pictures, and Professor T. Orhaug at the Swedish Försvarets Forskningsanstalt made arrangements for line-printer maps to be produced from ERTS digital tape. The Hydrologisk Avdeling at Norges Vassdrags- og Elektrisitetsvesen provided various technical assistance. Mr N. Haakensen and Miss S. Smith-Meyer assisted in the processing of ERTS images, height determinations, etc., Mrs Hansson drafted the maps and Mr B. Braskerud drafted most of the digrams. Last, but not least, Professor G. Hoppe gave most valuable support to the work in general, by stimulating discussions and comments. The author is most indebted to all those who have assisted in the work.

\section{REFERENCES}

Østrem, G. 1964. Glacio-hydrological investigations in Norway. Fournal of Hydrology (Amsterdam), Vol. 2, No. 2, p. IOI-15.

Ostrem, G. 1973. The transient snowline and glacier mass balance in southern British Columbia and Alberta, Canada. Geografiska Annaler, Vol. 55A, No. 2, p. 93-106.

Østrem, G., and Karlén, V. [1963.] Nigardsbreens hydrologi i 962 . En preliminær rapport om breens akkumulasjon og avsmeltning i tiden fra september 1961 til september 1962. Norsk Geografisk Tidsskrift, Bd. 18, Ht. $3-4,1961-62$, p. $156-202$.

Østrem, G., and Liestøl, O. 1964. Glasiologiske undersøkelser i Norge 1963. Norsk Geografisk Tidsskrift, Bd. 18, Ht. 5-6, $196 \mathrm{I}-62$, p. $28 \mathrm{I}-340$.

Schytt, V. 1966. Notes on glaciological activities in Kebnekaise, Sweden, during 1965. Geografiska Annaler, Vol. 48 A, No. 1, p. $43-50$.

Schytt, V. 1967. A study of ablation gradient. Geografiska Annaler, Vol. 49A, Nos. 2-4, p. 327-32.

\section{DISGUSSION}

M. F. MeIER: As part of our work with Stanford Research Institute on the analysis of ERTS images of snow cover, we have examined hundreds of plots of apparently snow-covered area versus grey-scale step. On none of these plots did we see any obvious "kink" or sharp change in slope which indicated the snow/no-snow boundary. Thus I believe more sophisticated identification procedures-such as multispectral analysis - will be required for accurate and rapid measurement. Have you tried any of these pattern recognition analysis techniques?

G. Østrem: No, so far we have only utilized the photographic method (with Agfacontour film) for density slicing, but we intend to start multispectral analysis from digital tapes. Further, in connection with the ERTS-B experiment, we will make ground observations at the time of every satellite pass, to collect more data about the actual snow conditions on the ground. Then we hope to find out which grey-scale level corresponds to a given snow cover, particularly in areas of scattered snow patches. 
M. DE Quervain: In the mapping of the altitude of the transient snow line in the Canadian Rocky Mountains the iso-lines appear to be very smooth. Normally a while after a snowfall, the transient snow line will be differentiated according to the exposure of a slope, sometimes by several $100 \mathrm{~m}$. How was this effect considered in these maps?

Øsтrem: The height of the transient snow line seems to form a more-or-less tilted surface cutting through the landscape, and its altitude increases throughout the summer. Disturbances in the general pattern may arise from summer snowfalls, but the pattern seems to re-establish itself after a couple of weeks or so.

Before iso-lines were drawn, a mean altitude was calculated for a cluster of glaciers, mainly $5^{-10}$ glaciers within one and the same mountain massif. In this work it appeared that certain glaciers always had a considerably lower (or higher) transient snow line altitude than the average. This happened every year, and it was always the same glaciers that showed deviations from the mean value. No special studies were made to investigate this further.

O. ORHEIM: You showed curves of cumulated run-off and degree-days versus changing snow line, and made the point that these curves were well correlated. Now we know from statistics that cumulative curves will show high correlations even if the variations with time of the different series are not correlated. I therefore wonder if these series are really well correlated, and if so whether this would not be better shown by plotting curves of the time variations of the series.

Østrem: I realize that the run-off is not always well correlated with the increasing height of the transient snow line, because liquid precipitation will make a contribution to run-off, independent of the snow-line height. There seems to be a better correlation between the height of the transient snow line (at the end of the melt season) and the specific mass balance, shown in Figures 7-8. The slide that was shown at the Symposium was used merely to indicate the connection between degree-days, run-off, and changing snow-line altitude. 